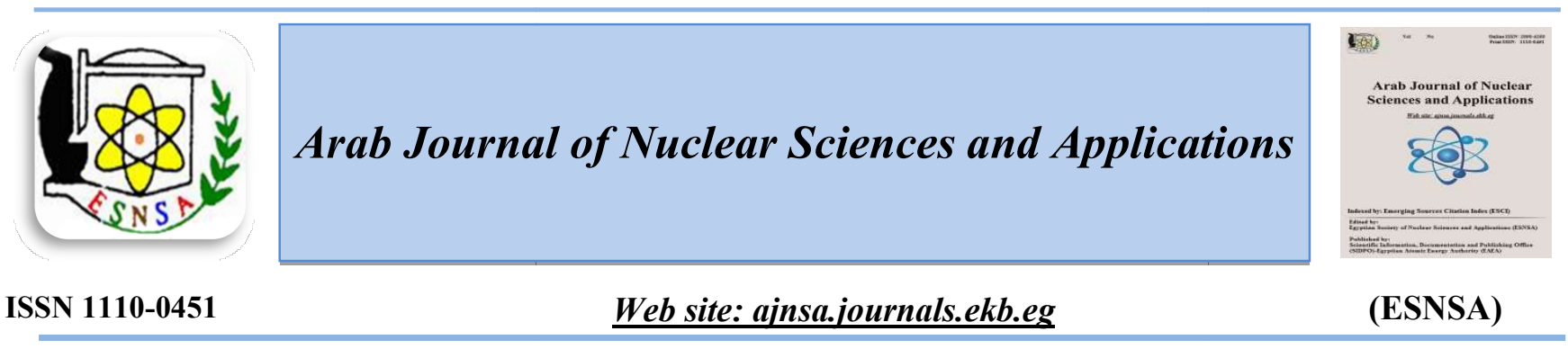

\title{
Effects of Radiofrequency Radiation Emitted from Mobile Phone on Hematological Parameters in Albino Mice
}

\author{
Mona H. Ibraheim ${ }^{1}$, Magda S. Hanafy ${ }^{1}$, Amir shahwan ${ }^{1}$ and Samir A. Nassar ${ }^{2 *}$ \\ ${ }^{I}$ Department of Physics, Faculty of Science, Zigzag University, Zigzag, Egypt \\ ${ }^{2}$ Department of Zoology, Faculty of Science, Zigzag University, Zigzag, Egypt
}

\begin{abstract}
Received16 ${ }^{\text {th }}$ March2020 Accepted $23^{\text {th }}$ June 2020

The present study aims at evaluating the effects of electromagnetic radiation EMR using mobile radiation $900 \mathrm{MHz}$ ( Nokia 3310, power $0.96 \mathrm{~W} / \mathrm{kg}$, intensity $1.3 \times 10-4 \mathrm{~W} / \mathrm{m} 2$ ) on some hematological parameters: White blood cells (WBC), Red blood cells (RBC), Hemoglobin (HB), Mean corpuscular volume (MCV), Mean corpuscular hemoglobin (MCH), Mean corpuscular hemoglobin concentration (MCHC), and Platelet count (PLT), Lymphocyte (LYM), Erythrocyte sedimentation rate (ESR), blood film, and osmotic fragility. Thirty adult male albino mice (25-30 gm weight) were divided into three equal groups; A, B, and C. Group A was used as a control one, group B was exposed to EMR for $1 \mathrm{hr}$ /day, and Group C was exposed to EMR for $2 \mathrm{hr} / \mathrm{day}$. The exposure time was three weeks, the results showed a reduced number of red blood cells and hematocrit \% for groups $B$ and $C$. However, it was important to observe that the number of WBCs and LYM \% increased and therefore reduced the damaging effect. Also, the erythrocyte sedimentation rate was faster than that of the control group. These results were supported by histology of blood cells, where irregularities and deformations in RBCs membranes have occurred. The osmotic fragility test showed a shift towards the low concentration of water after exposure to mobile radiation which indicates changes in the membrane permeability. It could be concluded that mobile radiation has harmful effects on the blood parameters of the exposed mice.
\end{abstract}

Keywords: Mobile phone radiation; Hematological parameters Sedimentation rate, Blood film, Osmoticfragility

\section{Introduction}

Blood parameters are the most important resources for determining the health status of experimental animals [1]. Mobile phones emit heat and radiofrequency radiation in the range of 800-2200 MHz as non-ionizing electromagnetic radiation [2]. These electromagnetic radiations have special thermal and non-thermal effects on biological systems [3]. There is a great concern about the possible adverse effects of heat and radiofrequency radiation from mobile phones on health.

There is evidence that exposure to radiofrequency (RF) radiation emitted from mobile phones or their unsuitable stations can affect the health of individuals [4]. The biological effects of mobile phone exposure to EMR have been identified as variable effects, depending on several factors, including exposure length, distance from different sources, kinds, and tissues as well as conditions of exposure [5].

Corresponding author:mhmekky@yahoo.com

DOI: 10.21608/ajnsa.2020.25830.1338

(C)Scientific Information, Documentation and Publishing Office (SIDPO)-EAEA 
Radiofrequency radiations emitted from the cell phone cause a significant decline in hematological parameters [6],[7] and highness of white blood cells (WBC) counts. Changes in hematological parameters may be due to electromagnetic radiation from cell phones that stimulates hemopoietic function in the bone marrow and oxidative stress that leads to unmanaged hemopoiesis that may eventually lead to anemia and bone marrow depression,this is also applied to other conditions for other abnormalities found in red blood cell deformation. [8].

RF fields can change the leucocyte activities, including more rapid changes (in the form of cell shrinking, expanding and rolling) and loss of its ability to move causing cell lysis and reducing their number. The electromagnetic radiations from cell phones damage the blood cells and produced an imbalance in blood enzymes. Increased cell apoptosis and functional disorders in many cell types also occur[9]. White blood cell count progression is also reported to exhibit tissue injury, WBC disorders (leukemia), and bone marrow disappointment. Therefore, the substantial increase of the WBC in the exposed animals was a strong indicator of stress-related effects and would encourage further studies on the immune impact of radiofrequency radiations on the radiated group.

This study is designated to evaluate the effects of radiofrequency radiation emitted from mobile phones on the hematological parameters of the exposed experimental mice. This study was achieved by measuring hematological parameters (RBC, HB, MCV, MCH, MCHC, WBC, P LT, LYM \%), erythrocyte sedimentation rate, blood film, and osmotic fragility test.

\section{Material and Methods}

\section{Experimental Animals}

Thirty adult male albino mice weighingh about 25-30 gm. were obtained from the breeding farm, Faculty of Veterinary Medicine,Zagazig University. Mice were divided randomly into three plastic cages for one week before the beginning of the experiment for adaptation. Mice were kept under constant environmental conditions at $25^{\circ} \mathrm{C} \pm 3$. Animals were divided equally into three groups ten for each. Group A, a control group ( unexposed ) kept under fixed situations of housing and handling until the day of sacrifice. Group B was exposed to the Mobile phone EMR for $1 \mathrm{hr} /$ day. Group C was exposed to the mobile phone EMR for $2 \mathrm{hr} /$ day. The whole bodies of mice were exposed to radiofrequency radiations emitted from the cell phone (Nokia 3310), daily for three weeks. Through the study, all animals containing the control group were fed on a laboratory diet and water ad libitum.

\section{Exposure Equipment}

A commercially available global system for mobile communication (GSM) cellular mobiles (Nokia 3310, Finland) were used in this study. This is the main network for operating mobile phones working in Egypt, peak power $0.96 \mathrm{~W} / \mathrm{kg}$, with a modulation type of Gaussian Minimum Shift Keying (GMSK), plus duration $4.6 \mathrm{~ms}$, a pulse frequency $217 \mathrm{~Hz}$ and the average power output $460 \mathrm{mw}$, intensity $1.3 \times 10-4 \mathrm{~W} / \mathrm{m}^{2}$.

\section{Laboratory analysis}

Hematological studies

Hematological assay: Blood samples were collected either on $0.2 \%$ EDTA anticoagulant for evaluation of arthrogramRed blood cells (RBC), White blood cells (WBC), Platelet count (PLT), Hemoglobin (HB), Mean corpuscular hemoglobin $(\mathrm{MCH})$, Mean corpuscular volume (MCV), Mean corpuscular hemoglobin concentration (MCHC), and leukogram (total and differential leukocytic count LCT), and on ammonium oxalate anticoagulant for platelets count PLT, using standard techniques according to the method described in a previous publication[10] and then stained with Leishman stain.

\section{Osmotic Fragility}

The osmotic fragility test of the whole blood was made for control and exposed groups [11]. Experiments were carried out within two hours of sample collection. Whole blood was additional to varying concentrations of buffered sodium chloride solution $\mathrm{NaCl}$ concentration $100 \mathrm{~g} / \mathrm{l} \mathrm{NaCl}$ buffered to $\mathrm{pH} 7.4$ and kept at $25^{\circ} \mathrm{C}$. The quantity of hemolysis was then determined by reading the absorbance of the supernatant through spectrophotometer using equation \% hemolysis= A540 of RBC treated sample-A540 of buffer/A540 of triton X100 (1\%)-A540 of the buffer where A540 is absorption at wavelength 540. (UV/ visible spectrophotometer Jasco V530), made in Japan[12]. 
Preparation of blood film

Preparation Techniques of blood film was conducted using Wedge methods [13]

Erythrocyte Sedimentation Rate (ESR) test

Erythrocyte sedimentation rate (ESR) is a blood test which evaluates how quickly RBCs settle at the bottom of a test tube containing a blood sample, which is $2 \mathrm{ml}$ of venous blood in a tube containing sodium citrate of $0.5 \mathrm{ml}$. This can be kept at room temperature at $4^{\circ} \mathrm{C}$ for no more than 2 hours or 6 hoursaccording to the Westergren method usedfor all samples at all conditions.

\section{Statistical analysis}

The data were analyzed using a statistical software package that is commercially available (SPSS v. 22.0). Results have been presented as \pm SD mean. The statistical significance was determined using the Student's t-test using the $\mathrm{p}<0.05$ level.

\section{Results}

\section{Hematological studies}

The results showed that there is a significant decrease at $(\mathrm{P}<0.05)$ in $\mathrm{RBCs}, \mathrm{Hb}, \mathrm{HCT} \%$, $\mathrm{MCV}, \mathrm{MCH}$, and, MCHC, PLT comparing with the normal group as shown in the Table (1).Each value in the Table is the means $\pm \mathrm{SD}$. Small letters $(a, b, c, d, \ldots \ldots)$ in the same row significantly different $(\mathrm{p} \leq 0.05)$ among experimental periods.

These results are in a good agreement with those of other researchers [6], [7].However, important observation was that the number of WBCs and LYM \% increased which reduces the damaging effect of the radiation

\section{Osmotic fragility test}

The osmotic fragility test is employed to help the diagnosis of different forms of anemia to test and study the physical properties of the red blood cells. The main factor affecting the fragility test is the shape of the RBCs, which in turn is dependent on the volume, surface, and functional state of the red blood cell membrane.

The mean values of the osmotic fragility test for the three different groups from a blood sample taken within two hours after exposure were used as a marker for fluctuations in the mechanical properties of RBCs as shown in Fig. (1). The hemolysis percentage for group $A$ was $(0.281 \pm 0.01),(0.340 \pm 0.01)$ for group $B$ and $(0.355 \pm 0.01)$ for $C$. The results of osmotic fragility amounts for RBCs collected from animals of diverse groups $\mathrm{A}, \mathrm{B}$, and $\mathrm{C}$, the percentages of hemolysis cells are planned as a function of the percentage of $\mathrm{NaCl}$ concentration. Osmotic fragility of RBCs increased and then hemolysis was faster and ruptured much more quickly for mice of an exposed group than the control group. Fig. (1) explains the osmotic fragility curve which can give good information about changes that may occur for the RBCs membrane elasticity and ionic absorbency [14], which play a major role in the metabolic activities of RBCs. The shift of osmotic fragility after exposure to mobile radiation indicates changes in the membranepermeability to water molecules. The changes in the RBCs permeability will cause a disturbance intheir function and mutual interactions with neighboring cells.

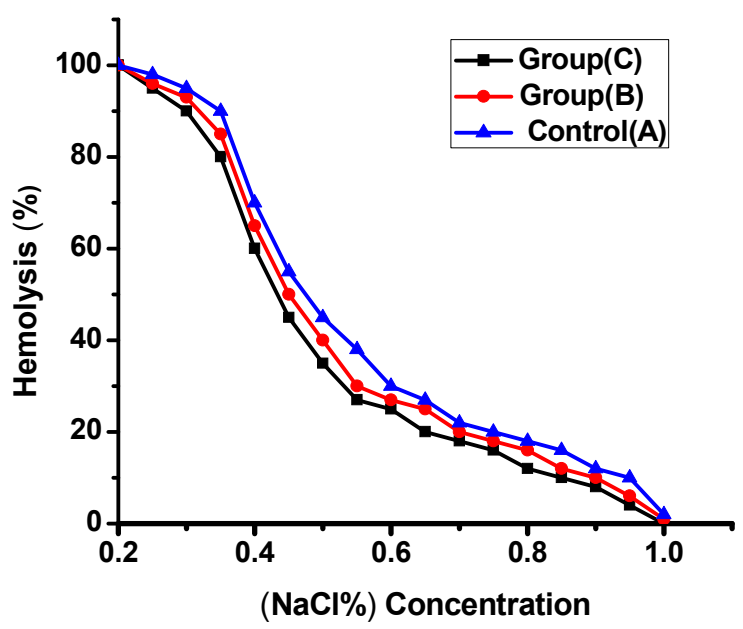

Fig. (1): The Osmotic fragility for differential curves from samples

\section{Blood film \\ Control group (A)}

Fig. (2) Explains the blood film of group A (normal mice) showing intact leucocyte (straight arrow) and erythrocytes. The cells have regular sizes and form as pellets with a compound of hemoglobin. 


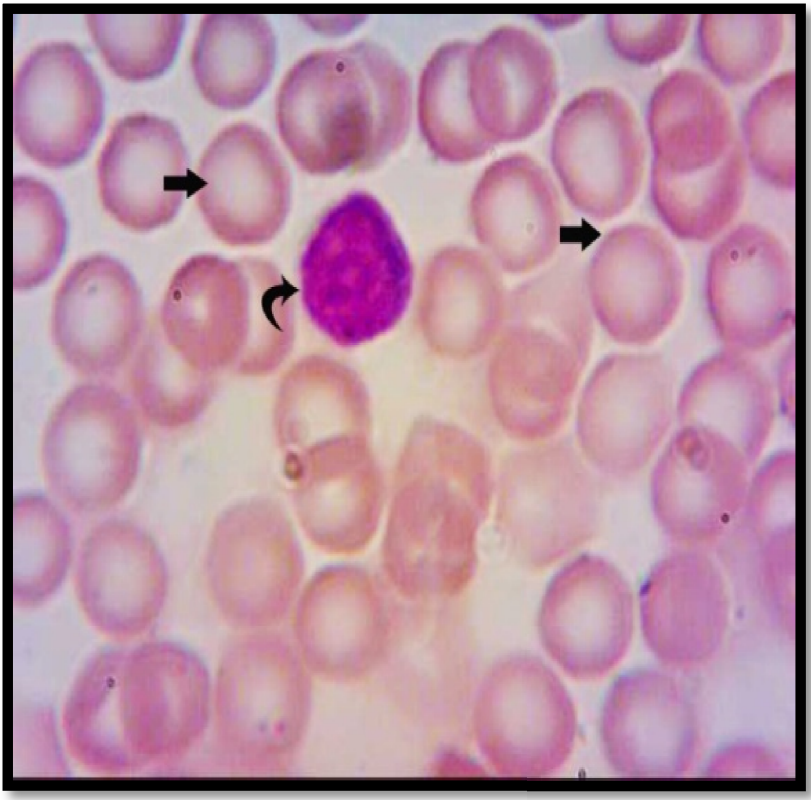

Fig. (2): Blood film of control mice showing intact leucocyte (curved arrow) and erythrocytes (straight arrow)

\section{Exposed group (B)}

When animals were exposed to mobile phone radiation, the red blood cells took their normal shape to a large extent close to the structure of the control group and there were also some cells accumulated next to each other to form rouleaux, all cell-shaped compacts intermittently appear in the line.The appearance of cells in this configuration was attributed to the tendency of red blood cells to bind with each other and collected after each other due to increased blood viscosity when exposed to any stimuli.Fig. (3) explains that red blood cells with serrated walls have been seen with a different number of humps and other surrounding red blood cells that have been seen from the outside, including red blood cells with borders, cells called burr cells, or Echinocytes erythrocytes.

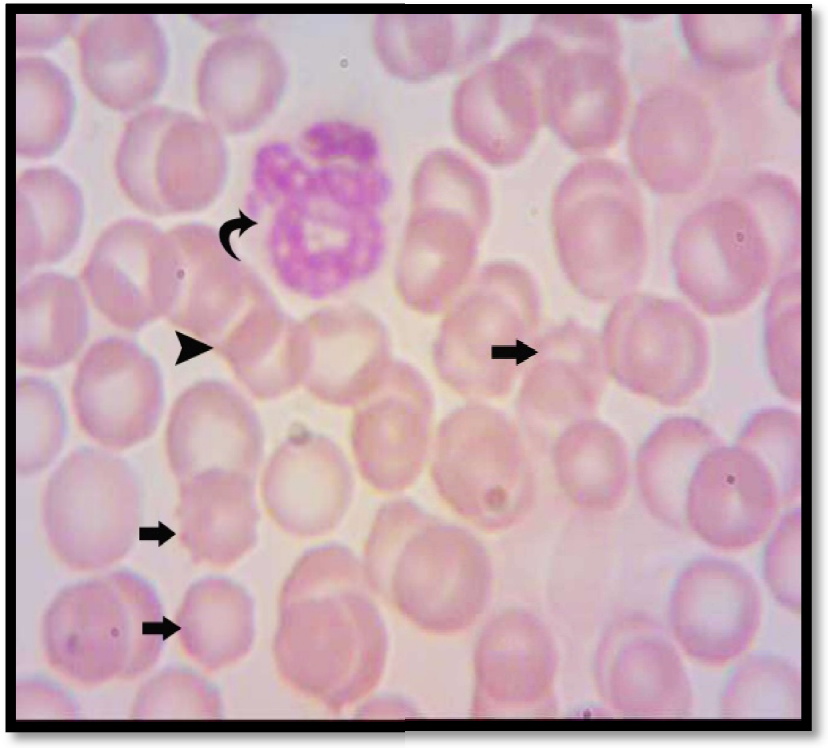

Fig. (3): Blood film of the exposed mice group B, RBCs morphology exhibiting fragmented leucocytes (curved arrow), crenated $\mathrm{RBC}_{\mathrm{s}}$ (straight arrows) and other erythrocytes in rouleaux formation (arrowhead)

\section{Exposed group $(C)$}

Fig. (4) explains the blood smear of the exposed mice group $\mathrm{C}$. The Figure showsthe $\mathrm{RBCs}$ morphology. The RBC deformity (arrow) is shown in Fig. (4)which referred to as a "bite" cell, is an abnormally shaped red blood cell with one or more semicircular portions removed from the cell margin. These "bites" result from the removal of denatured hemoglobin by the stress of radiation.

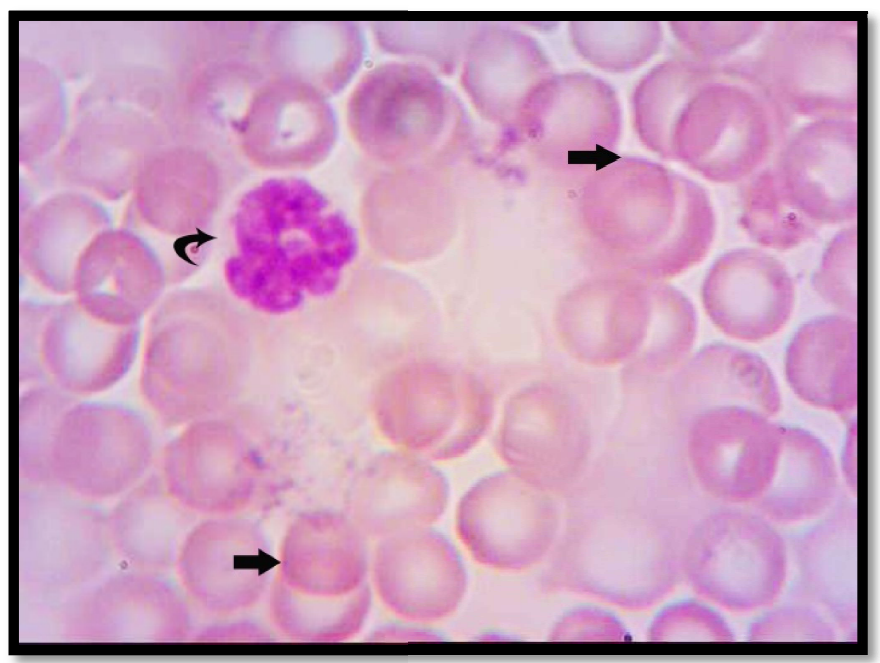

Fig. (4): Blood film of the exposed mice group $C$, showing leucocyte (curved arrow) and erythrocytes (straight arrows) 


\section{Erythrocyte Sedimentation Rate (ESR) results}

$\mathrm{RBC}$ sediment because its density is higher than that of the plasma; this is particularly the case when there is a shift in the distribution of charges on the surface of the RBC resulting in large aggregates known as rouleaux getting merged Table (2).

\section{Discussion}

The blood parameters are the most significant means to determine the health status of the experimental animals [1]. Thus, studying the RF radiation effects from cell phones on the hematological parameters indicates the dangerous impacts of radiofrequency radiation on the exposed animals. This is because of the fact that the blood reflects the pathophysiology of the whole body. In the present study, the results showed that electromagnetic radiation from cell phones causes statically significant changes in RBCs, Hb, HCT, MCV, MCHC, PLT, and WBCs levels which are in a good agreement with that reported in other publications $[6,15,16]$.

Exposure to cell phone radiation increases the concentration of peroxynitrite that can interfere with the proper function of cells and damage it. Also, it increases the activity of superoxide which makes erythrocytes more susceptible to oxidative damage due to continuous exposure to high oxygen tension with large quantities of iron, a potent catalyst for oxygen-free polyunsaturated fatty acids which are the main targets for peroxidation [17].

The electromagnetic radiations from cell phones have damaging effects on the blood cells, producing imbalance in blood enzymes, increasing cell apoptosis, and functional disorders in many cell types [9]. White blood cell count progression indicates tissue damage, white blood cell disorders (leukemia), and bone marrow depression. The significant increase of the white blood cells was therefore a good indication of stress-related effects in the exposed animals and should encourage further study of the immunological effect of radiofrequency radiation on the exposed population[7].

Exposure to cell phone radiation increases the concentration of peroxynitrite that can interfere with the proper function of cells and damage it. It also increases superoxide activity. Erythrocytes are vulnerable to oxidative damage due to continuous exposure to high oxygen tension and the presence of a large amount of iron, a potent catalyst for oxygen-free polyunsaturated fatty acids which are major targets for peroxidation [17] and [18].

Red blood cells normally settle in a relatively slow manner. A rate that is faster than normal can indicate inflammation in the body. Inflammation is an integral part of your immune response as a response to an infection or an injury. Also, inflammation can be an indication of chronic illness, immune disease, or other medical conditions.

Changes in the form or numbers of red cells may also influence the ESR. The formation of rouleaux is primarily determined by increased levels of globulins and fibrinogen. Representing variations in plasma proteins that proceed with acute and chronic infections, ESR also detects certain tumors and degenerative diseases. In such cases, the ESR values are much higher than $20 \mathrm{~mm} / \mathrm{hr}$. It should be noticed that the ESR not only denotes the presence, but also the extent of tissue damage; it can be used to track disease progress or treatment effectiveness $[19,20]$.

Abnormalities deformities in red blood cells include changes in shapes and sizes of red blood cells [6]. In the present study ( blood film ), a significant decrease in superficial charge density of red blood cells was observed. Also, they increased their aggregation and density leading to the construction of rouleaux and cause cell lysis[21]. The deformities in RBCs morphology suggested a possible relationship between exposure to cell phone radiation and depression of the bone marrow that causes multiple myeloma, reduced number of blood cells, myelofibrosis, and thalassemia [22].

The ease with which RBCs undergo lysis when kept in a hypotonic solution is osmotic fragility. The higher intracellular osmotic pressure drains water into the red blood cells when placed in hypotonic saline. Consequently, the cells are spherical and the red cell membrane eventually makes way for the release of hemoglobin into the surrounding fluid. Hemoglobin releases from the red blood cells in a known process as hemolysis. The importance of estimating osmotic fragility lies in the fact that it provides details about the overall state of red cell metabolism and the strength of the membrane. A large increase in osmotic fragility of the mice has been observed in 
the present research. Similar findings were observed by other researchers[23] and [24].

Radiofrequency emitted from mobile phones have harmful effects on different organs and tissues. In contrast, other studies suggested that no effects have been observed after exposure to cell phone radiation. Thus, numerous studies should be done in different fields to show more facts on the effects of cell phones radiation according to international standards for protection.

Table (1): Mean value of hematological factors caused by radiofrequency radiations which produced from a mobile phone in the albino mice groups compared with the control

\begin{tabular}{cccc}
\hline Blood parameters & Control (A) & Group(B) & Group(C) \\
\hline $\mathrm{RBC}\left(\mathrm{x} 10^{6} / \mu \mathrm{l}\right)$ & $9.07^{\mathrm{a}} \pm 0.02$ & $8.38^{\mathrm{b}} \pm 0.02$ & $7.83^{\mathrm{c}} \pm 0.75$ \\
$\mathrm{HB}(\mathrm{g} / \mathrm{dl})$ & $12.30^{\mathrm{a}} \pm 0.01$ & $12.09^{\mathrm{b}} \pm 0.01$ & $11.89^{\mathrm{c}} \pm 0.01$ \\
$\mathrm{HCT}(\%)$ & $53.89^{\mathrm{a}} \pm 0.01$ & $48.09^{\mathrm{b}} \pm 0.01$ & $41.40^{\mathrm{c}} \pm 0.01$ \\
$\mathrm{MCV}((\mathrm{fL} / \mathrm{cell})$ & $59.31^{\mathrm{a}} \pm 0.01$ & $55.39^{\mathrm{b}} \pm 0.01$ & $50.39^{\mathrm{c}} \pm 0.01$ \\
$\mathrm{MCH}((\mathrm{pg} / \mathrm{cell})$ & $13.48^{\mathrm{a}} \pm 0.02$ & $12.69^{\mathrm{b}} \pm 0.02$ & $12.39^{\mathrm{c}} \pm 0.01$ \\
$\mathrm{MCHC}(\mathrm{g} / \mathrm{dl})$ & $22.77^{\mathrm{ab}} \pm 0.14$ & $22.33^{\mathrm{b}} \pm 0.08$ & $23.33^{\mathrm{a}} \pm 1.21$ \\
$\mathrm{WBC}\left(\mathrm{x} 10^{3} / \mu \mathrm{l}\right)$ & $8.00^{\mathrm{c}} \pm 1.26$ & $15.57^{\mathrm{a}} \pm 0.15$ & $9.78^{\mathrm{b}} \pm 0.17$ \\
$\mathrm{PLT}\left(\mathrm{x} 10^{3} / \mu \mathrm{l}\right)$ & $1300.83^{\mathrm{a}} \pm 2.32$ & $782.33^{\mathrm{b}} \pm 1.97$ & $562.00^{\mathrm{c}} \pm 2.09$ \\
$\mathrm{LYM} \%$ & $23.50^{\mathrm{c}} \pm 3.27$ & $73.00^{\mathrm{a}} \pm 2.61$ & $43.00^{\mathrm{b}} \pm 2.61$ \\
\hline
\end{tabular}

Table (2): Explain the changes in the values of Erythrocyte Sedimentation Rate for $2 \mathrm{ml}$ blood sample due to radiofrequency radiations from a mobile phone in the albino mice groups compared with the control

\begin{tabular}{cccc}
\hline Treatment & Control (A) & Group(B) & Group(C) \\
\hline $\begin{array}{c}\text { Erythrocyte } \\
\begin{array}{c}\text { Sedimentation Rate } \\
(\mathrm{mm} / \mathrm{hr})\end{array}\end{array}$ & $2(\mathrm{~mm} / \mathrm{hr})$ & $5(\mathrm{~mm} / \mathrm{hr})$ & $7(\mathrm{~mm} / \mathrm{hr})$ \\
\hline
\end{tabular}

\section{Conclusions}

As a result of the present experiment, we can figure out that radiofrequency emitted from mobile has its dangerous effects not only on the blood count, but also on the blood itself from its sedimentation rate and osmotic fragility. Lowering the RBC, WBC count, increasesthe damaged RBC. Radiofrequency now becomes known for why many people may get anemia and such other diseases. Hence, it is recommended to get control over our mobile phones in terms of use of social media and calls for its now known damaging effects on the whole blood parameters of our bodies.

\section{References}

1. Soud. (2004), Human and the Environment (Education Study of the Environment). Dar Al-Hamed for Publication and Distribution," Journal of Environmental Studies, 1, 23-31 
2. Bhargava, S.; Motwani, M. B.; Patni, V. M., (2012 ), Effect of handheld mobile phone use on parotid gland salivary flow rate and volume. Oral surgery, oral medicine, oral pathology, and oral radiology, 114 (2), 200-206.

3. Anan, H., Gawish H.; F., Amer, M.,( 2012), Effects of Low Magnetic Irradiation on Morphology and Ultrastructure of Parotid Glands in Rats and Amelioration by Vitamin E. Journal of Cytology \& Histology, 03 (02).

4. Hao, Y.-H.; Zhao, L.; Peng, R.-Y., (2015), Effects of microwave radiation on brain energy metabolism and related mechanisms. Military medical research, 2 (1), 4.

5. Ahlbom, A.; Bridges, J.; de Seze, R.; Hillert, L.; Juutilainen, J.; Mattsson, M. O.; Neubauer, G.; Schuz, J.; Simko, M.; Bromen, K., (2008), Possible effects of electromagnetic fields (EMF) on human health--the opinion of the scientific committee on emerging and newly identified health risks (SCENIHR). Toxicology, 246 (2-3), 248-50.

6. Singh, H.; Bagai, U.,( 2013), Effect of electromagnetic field on red blood cells of adult male swiss albino mice. Int $\mathrm{J}$ TheorApplSci, 5 (1), 175-82.

7. Kumari, P.; Manjula, S.; Gautham, K., (2016), ( In vitro study of effect of radiation emitted by mobile phone on osmotic fragility and other blood parameters. Research Journal of Pharmaceutical, Biological and Chemical Sciences 7 (4), 1283-1292.

8. Aberumand, M.; Mansouri, E.; Pourmotahari, F.; Mirlohi, M.; Abdoli, Z., (2016), Biochemical and histological effects of mobile phone radiation on enzymes and tissues of mice. Research Journal of Pharmaceutical Biological and Chemical Sciences 7 (5), 1962-1971.

9. Atasoy, A.; Sevim, Y.; Kaya, I.; Yilmaz, M.; Durmus, A.; Sonmez, M.; Omay, S.; Ozdemir, F.; Ovali, E., (2009), The effects of electromagnetic fields on peripheral blood mononuclear cells in vitro. BratislLekListy, 110 (9), 526-9.

10. Mitchell Lewis, MD, FRC path, Barbara $\mathrm{J}$, and Imelda Bates Dacie and PaganaKD and Pagana TJ. Mosbys Manual of Diagnostic and laboratory Tests Louis mosbymos by Elsevier. (2010).

11. DacieJV ., and Lewis SM., (1996), Practical Hematology,7th ed. (Charchill and Livingston, London, 196-200).

12. Brown, B. A., Hematology: principles and procedures. Lea \&Febiger: Philadelphia, 1993.

13. Tkachuk, D. C.; Hirschmann, J. V.; Wintrobe, M. M., Wintrobe's Atlas of clinical hematology. Lippincott Williams \& Wilkins: 2007.

14. VISCOR, G. \& PALOMEQUE, J., (I982); Method for determining the osmotic fragility curves of erythrocytes in birds, Laboratory Animals 16, 48-50.

15. Guo, L.; Zhang, J. P.; Zhang, K. Y.; Wang, H. B.; Wang, H.; An, G. Z.; Zhou, Y.; Meng, G. L.; Ding, G. R.,( 2018), Effects of $1.8 \mathrm{GHz}$ radiofrequency field on microstructure and bone metabolism of femur in mice. Bioelectromagnetics, 39 (5), 386-393.

16. Guo, L.; Lin, J.-J.; Xue, Y.-Z.; An, G.-Z.; Zhang, J.-P.; Zhang, K.-Y.; He, W.; Wang, H.; Li, W.; Ding, G.-R., (2019 ), Effects of $220 \mathrm{MHz}$ pulsed modulated radiofrequency field on the sperm quality in rats. International journal of environmental research and public health, 16 (7), 1286.

17. Hasan, H.; Issmer, A., (2014), Effect of emitted radiation from mobile phones and its base station antennas on some biochemical parameters in human red blood cells. Int. J. Sci. And Engin. Res, 5 (3), 965-970.

18. Ahlers, M. T.; Ammermuller, J., (2014), No influence of acute RF exposure (GSM900, GSM-1800, and UMTS) on mouse retinal ganglion cell responses under constant temperature conditions. Bioelectromagnetics, 35 (1), 16-29.

19. Thue, G.; Sandberg, S.; Fugelli, P., (1994 ), The erythrocyte sedimentation rate in general practice: clinical assessment based on case histories. Scandinavian journal of clinical and laboratory investigation, 54 (4), 291-300. 
20. Lluberas-Acosta, G.; Schumacher, J. H., (1996), Markedly elevated erythrocyte sedimentation rates: consideration of clinical implications in a hospital population. The British journal of clinical practice, 50 (3), 138-142.

21. Yong, J.; Ruan, P.; Shen, H., (2013 ), Monitoring the radiation injury of red blood cells to microwave radiation with different power density. Engineering, 5 (10), 450-454.

22. Hoffman, M.; Blum, A.; Baruch, R.; Kaplan, E.; Benjamin, M., (2004), Leukocytes and coronary heart disease. Atherosclerosis, 172 (1), 1-6.

23. Chow, J.; Phelan, L.; Bain, B. J., (2005), ( Evaluation of single-tube osmotic fragility as a screening test for thalassemia. American journal of hematology 79 (3), 198-201.

24. Chikezie, P., (2007). Osmotic fragility index of HBAA red blood cells in the presence of aqueous extracts of three medicinal plants (Aframomummelegueta, Garcina kola, and Cymbopogoncitracus). Global Journal of Pure and Applied sciences, 13 (4), 497-499. 